\title{
Molecular taxonomy of Plagioscion Heckel (Perciformes, Sciaenidae) and evidence from mtDNA RFLP markers for an invasive species in the Paraná river, Southern Brazil ${ }^{1}$
}

\author{
Rodrigo A. Torres ${ }^{2}$ \\ ${ }^{1}$ Contribution number 1674 do Departamento de Zoologia, Universidade Federal do Paraná. \\ ${ }^{2}$ Laboratório de Genômica Evolutiva e Ambiental, Departamento de Zoologia, Centro de Ciências Biológicas, Universidade \\ Federal de Pernambuco. Avenida Professor Moraes Rego, 50670-420 Recife, Pernambuco, Brasil. Email: rodrigotorres@ufpe.br
}

\begin{abstract}
Mitochondrial RFLP markers were developed to examine whether Plagioscion squamosissimus (Heckel, 1840) is invasive in natural environments of the congener P. ternetzi in the Paraná river, in southern Brazil. Specimens of $P$. squamosissimus and of the putative P. ternetzi (Boulenger, 1895) were obtained from the Negro river (Manaus, Amazonas, Brazil) and from Paraná river, respectively. Fragments of the cytochrome b gene (900bp) were amplified by PCR and four restriction enzymes (Eco RI, Mbo I, Bam HI and Alu I) yielded the mitochondrial markers. An additional RFLP analysis with a cytochrome b gene sequence of Plagioncion sp. from GeneBank was carried out to validate the prior analysis. No genetic differentiation was found among either sample. While molecular variation in the cytochrome $b$ analysis was no substantial among individuals, the combined analysis was important for demonstrating that there is no evidence for differentiation of the putative sample $P$. ternetzi from that of $P$. squamosissimus. The ecological implications of the introduced occurrence of $P$. squamosissimus, as well as the role of molecular taxonomic approaches for biodiversity studies are discussed.

KEY WORDS. Plagioscion squamosissimus; Cytochrome b; genetic identity; biological invasions.
\end{abstract}

RESUMO. Taxonomia molecular de Plagioscion Heckel (Perciformes, Sciaenidae) e evidências de marcadores moleculares RFLPs de mtDNA para uma espécie invasora no rio Paraná, Sul do Brasil. Marcadores RFLPs mitocondriais foram desenvolvidos para verificar se Plagioscion squamosissimus (Heckel, 1840) é invasora nos ambientes naturais da espécie congênere P. ternetzi no rio Paraná, no sul do Brasil. Exemplares de Plagioscion squamosissimus e supostamente de P. ternetzi (Boulenger, 1895) foram obtidos, respectivamente, do rio Negro (Manaus, AM, Brasil) e rio Paraná (Foz do Iguaçu, PR, Brasil). Foram amplificados, via PCR, fragmentos de cerca de 900pb do Citocromo b e foram utilizadas quatro enzimas de restrição (Eco RI, Mbo I, Bam HI e Alu I) para os fins de geração dos marcadores moleculares. Foi desenvolvida, a partir de uma seqüência de Citocromo b de Plagioscion sp. (genebank), uma análise de RFLP adicional, objetivando validar a primeira análise acima mencionada. Considerando a inexistência de significativa variação observada no Citocromo b dos indivíduos analisados, a análise combinada com todas as enzimas foi importante para demonstrar que não existe diferenciação molecular para o nível específico entre a suposta amostra de P. ternetzi e aquela de Plagioscion squamosissimus. São discutidas as implicações ecológicas da introdução de P. squamosissimus, bem como a aplicação da taxonomia molecular para estudos de biodiversidade. PALAVRAS-CHAVE. Plagioscion squamosissimus; Citocromo b; identidade genética; invasões biológicas.

Molecular phylogenetics and systematics have shown great strides in recent years, due to the development of new and diverse methods for analysis of molecular DNA markers. These methods allow assessing the genetic variability of the biota carrying to a superestimation on the global biodiversity besides the relationships among taxa (GRECHKo 2002). Molecular taxonomic approaches may be defined as DNA-based methods that permit an exact and rapid method of distinguishing specimens based on their interspecific variations. Molecular taxonomy has many benefits such as (1) data can be obtained from a single specimen, (2) morphologically indistinguishable taxa can be separated, (3) all stages and morphs of taxa are accessible and (4) a single technique is applicable to all taxa, such as RFLP markers (BLAXTER \& FLOYd 2003).

Plagioscion Gill, 1861 (Sciaenidae) is a neotropical freshwater genus of fish comprising seven species (sensu FroESE \& 
Pauly 2006, Soares \& Casatti 2000, Aguilera \& Aguilera 2000). Plagioscion squamosissimus (Heckel, 1840) is widely distributed throughout the Orinoco, Amazon and Parnaíba basins, and was also introduced into reservoirs of northeastern Brazil during the 1970s. Currently, it is among the dominant species in the Itaipu reservoir (Benedito-CeCilio \& Agostinho 2000). In that reservoir, the species varies with respect to the size at maturation and location and timing of the spawning season (CARnelós \& BeneditoCECILIO 2002). Plagioscion squamosissimus is an opportunistic fish predator (fishes comprise $80 \%$ of its diet) (TORLONI et al. 1993, Braga 1998, Loubens 2003).

Human impacts on the ecosystems continue to grow (McNeely 1996). One critical element in this increased impact is the movement of organisms from one region to another through trade, transport, and tourism. Many of these introductions of organisms into new ecosystems are beneficial to people and detrimental to the ecosystem receiving them. Thus, an invasive species may be defined as a species whose establishment and spread threatens ecosystems, habitats or species with economic or environmental harm (ColAutTI \& MACISAAC 2004). Since P. squamosissimus may be considered as an invasive species into the Paraná river, here we wished to confirm its occurrence in natural environments of the endemic Plagioscion ternetzi (Boulenger, 1895), downstream to the Itaipu powerplant, based on MT (molecular taxonomy) analysis.

\section{MATERIAL AND METHODS}

Ten specimens of P. squamosissimus were obtained from the Negro river (Manaus, Amazonas, Brazil; Figs $1 a_{1} / a_{2}$ ) and thirteen specimens of the putativeP. ternetzi were obtained from the Paraná river, downstream from the Itaipu power plant (Foz do Iguaçu, Paraná, Brazil; Figs $1 b_{1} / b_{2}$ ). Of these, 5/6 individuals (see results for details) of P. squamosissimus from Amazon basin and 6 individuals of the putative P. ternetzi were analysed. Genomic DNA was isolated from ethanol-preserved muscle tissue by the Salting-out methodology (MILLER \& POLESKI 1998).

The mitochondrial cytochrome $b$ gene was amplified by polymerase chain reaction (PCR) in $25 \mu$ l reactions containing $4 \mu \mathrm{l}$ dNTPs (5mM), $2.5 \mu \mathrm{l}$ reaction buffer (10X), $2 \mu \mathrm{l} \mathrm{MgCl}_{2}$ $(25 \mathrm{mM}), 2 \mu \mathrm{l}$ of each primer $(10 \mu \mathrm{M}), 1 \mu \mathrm{l}$ Taq DNA polymerase (1U/ $\mu \mathrm{l}), 2 \mu \mathrm{l}$ of template DNA $(50 \mathrm{ng} / \mu \mathrm{l})$ and $9.5 \mu \mathrm{l}$ of $\mathrm{H}_{2} \mathrm{O}$. PCR conditions were as follows: 30 cycles of $94 \circ \mathrm{C}$ ( $1 \mathrm{~min}), 40$ ㅇ (45secs.), 72으 (90secs), 18 cycles 94으 (1min), 53으 (30 secs), $72^{\circ} \mathrm{C}$ (1min). The following primers set were used for PCR: Cytblscie 5' CGAAACTAATGACTTGAAAAACCACCGTTG 3' and Cytbhscie 5' AAATAGGAARTATCAYTCTGGTTTRAT 3'. Both, PCR conditions and the primers used followed SANTOs et al. (2003).

RFLP markers were yiel ded by using 4 restriction enzymes (Tab. I). Experiments used $1 \mu$ of the PCR-based fragments plus $1 \mathrm{U}$ of each enzyme at 37 으 for three hours following the manufacturer's suggestions. The products were resolved by electrophoresis in $1 \%$ agarose gels run with TBE buffer $(0.89 \mathrm{~m}$ Tris, $0.89 \mathrm{~m}$ boric acid and $0.08 \mathrm{~m}$ EDTA, pH 8.3). Electrophore- sis was conducted at $3 \mathrm{~V} / \mathrm{cm}^{-1}$. Gels were stained with ethidium bromide and the image was captured by using the digital gel documentation system Vilber Lourmat IP.010.SD.

An additional analysis used a Cytochrome $b$ sequence from Plagioscion sp. (genebank accession $n \cong$ Y 374296 ) to verify the consistency of the mtDNA markers. Thus, the number of restriction site repeats within each sequence was verified and compared, given each enzyme used.

Table I. Summary of the restriction enzimes used with their sequence restriction sites (arows).

\begin{tabular}{lc}
\hline Enzime & Sequence restriction site \\
\hline Alu I & AG $\downarrow$ CT \\
Bam HI & G $\downarrow$ GATCC \\
Eco R & G $\downarrow$ AATTC \\
Mbo I & $\downarrow$ GATC \\
\hline
\end{tabular}

\section{RESULTS}

Fragments (approximately 900bp) were obtained from the mitochondrial cytochrome b gene in all samples (Fig. 2a). The Eco RI and Mbo I restriction profiles presented a single band of 900bp for both Paraná and Negro river samples (Figs $2 b, d)$. The restriction profilefor Bam $\mathrm{HI}$ was an identical 725bp band in both samples (Fig. 2e). Alu I restriction profile was the most revealling and had three bands, corresponding to 400 , 275 and 225bp (Fig. 2c).

The additional RFLP analysis involving the 1085bp of the Cytochrome $b$ sequence collected from genebank revealed the high consistency for the mtDNA markers. Specific RFLP markers were observed for the species sampled in the confluence between Amazonas and Tamshiyacu rivers in Peru (SLoss et al. 2004) (Figs 3a, b, c, d).

\section{DISCUSSION}

DNA/PCR-based analyses have been considered one of the most important methodological revolutions for biodiversity analysis (WHELAN 2001)

PCR results showed that the primer set performed well, by amplifying a single band corresponding to a fragment of the cytochrome b gene, (Fig 2a) for all specimens analyzed (also see SANTOS et al. (2003) for Macrodon ancylodon Bloch \& Schneider, 1801). Also, it suggests that very similar flanking complementary sequences such as 5'GCTITGATTACTGAACTIITGGTGGCAAC 3' and 5' TITATCCTTRATAGTYAGACCAAARTA 3' could be conserved in the sciaenid cytochrome b gene. The 900bp for the cytochrome $b$ gene of Plagioscion specimens here studied are very similar with that obtained from genebank (Plagioscion sp.), suggesting an average size of 900-1000bp for this mitochondrial gene, similar to those from several representatives of the main fish groups (Tab. II). Such molecular genetic pattern seems to be also

Revista Brasileira de Zoologia 23 (4): 1235-1242, dezembro 2006 


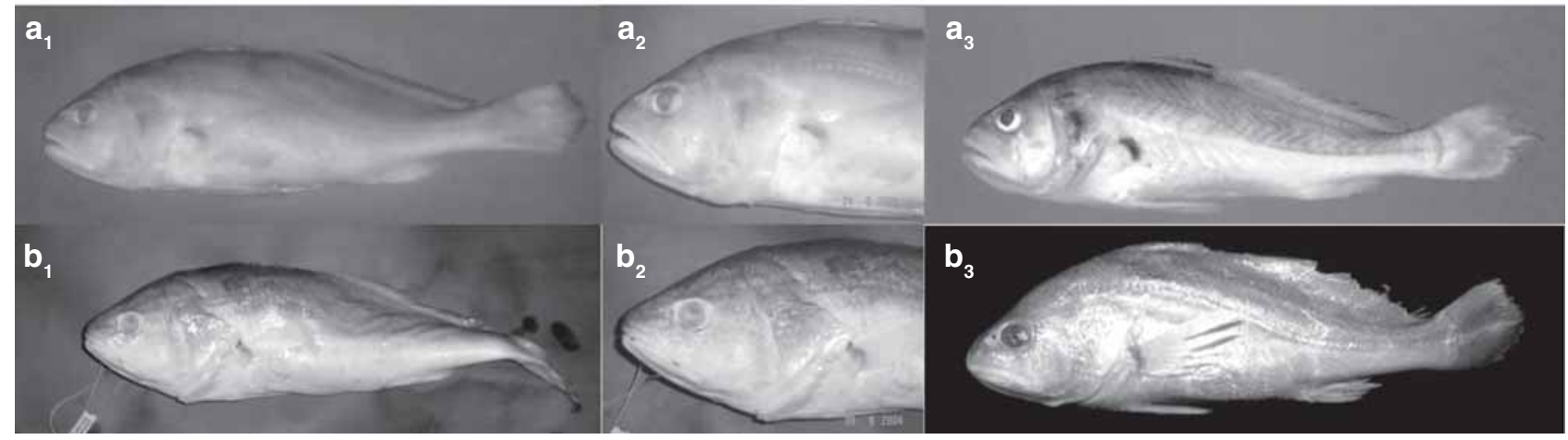

Figure 1. Samples $\left(a_{1} / a_{2}\right)$ Plagioscion squamosissimus from the Rio Negro (Manaus, Amazonas, Brazil); $\left(a_{3}\right)$ Plagioscion squamosissimus (photo by Ana L. Casatti); $\left(b_{1} / b_{2}\right)$ Putative sample of Plagioscion ternetzi from the Paraná river (Foz do Iguaçu, Paraná, Brazil); $\left(b_{3}\right)$ Plagioscion ternetzi (photo by Dra. Lilian Casatti).

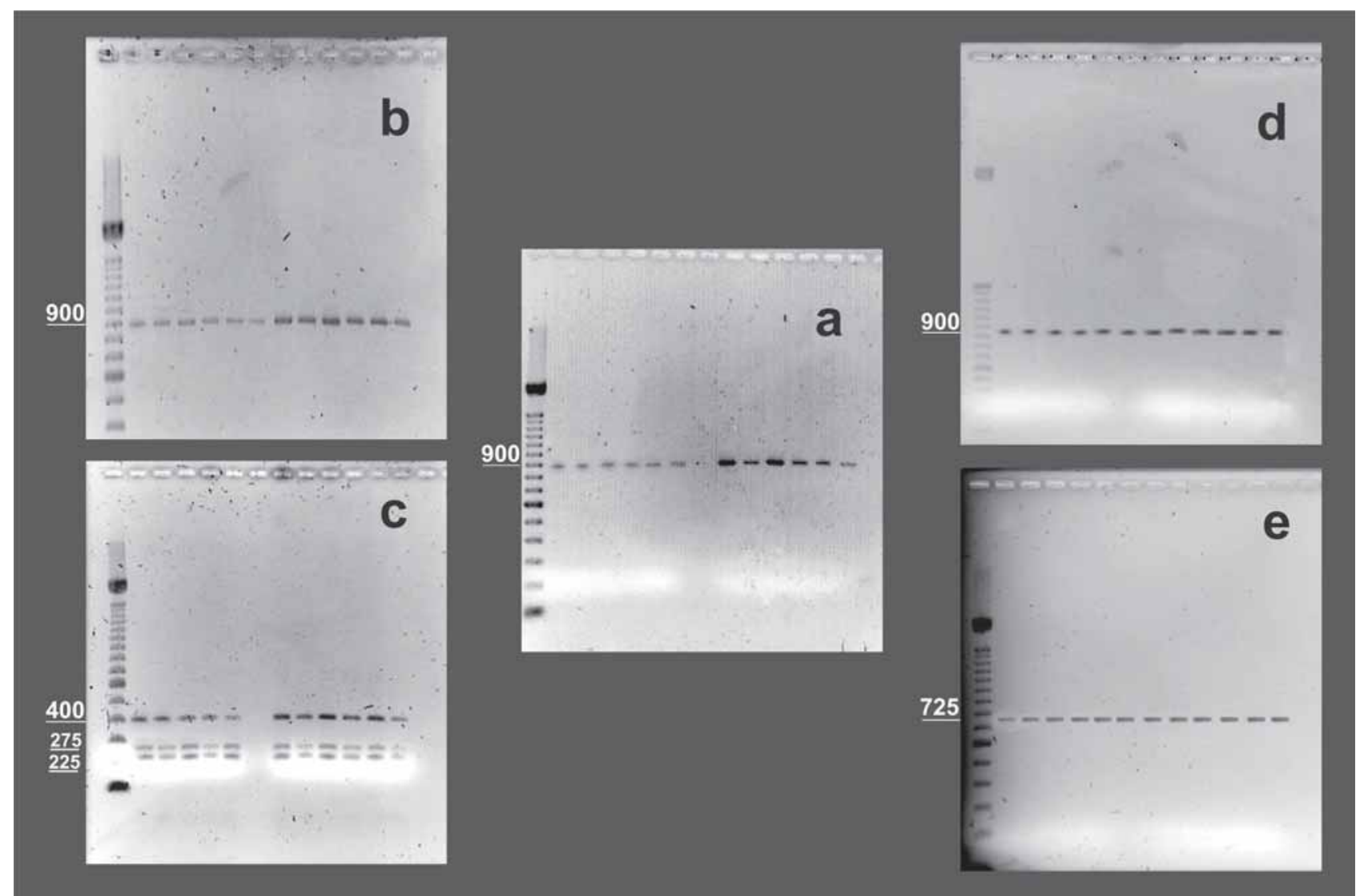

Figure 2. PCR and RFLP profiles. In (a) PCR products of the cytochrome b gene of 900bp; (b) and (d) the single band (900bp) yielded with EcoRl and Mbol enzymes, respectively; (c) RFLP profiles using the Alul enzyme; (e) the single band (725bp) obtained with BamH1 enzyme. The first 5/6 specimens (left to right) are of P. squamosissimus. The other individuals are putatively P. ternetzi.

a common feature among vertebrates considering that similar sizes are also detected in members of mammals, such as bats and rodents (Bradley \& BaKer 2001).
Mitochondrial DNA has been extensively studied in fish and most vertebrate groups (Moyses \& Almeida-Toledo 2002, Jérôme et al. 2003, Palo \& Merilä 2003, Reedle et al. 2003,

Revista Brasileira de Zoologia 23 (4): 1235-1242, dezembro 2006 
a)

cccacccactcctaaaatcgctaacgacgcactggtagatctcccogcccatccaacatctcagcetgatg aaatttggatccctgctcggtctctgcttagccgcccaaatcctcacaggactcttcctagccatgcactac acagctgacatctccatagccttctcatccgtcgcgcacatttgccgagatgttaactacggctgactcatcc gaaacctccatgccaacggcgcctccttcttct tcatctgcctctacctccacatcggccgaggcctttacta cggctcctatctttacatagaaacatgaaacatcggggtcattctttccttttagtaatgataaccgccttc gttggctatgtccttccatgaggtcaaatatctttctgaggtgccaccgtcattacaaacttctgtctgctg taccgtatgtgggtaacacactagtccaatgaatttgaggaggattctccgtagacaacgccaccetcac ccg cttcttcgccttccacttcctcctccatttatcgtcacagctgctaccettctccacctacttttcctgcac gaaacaggatcaaacaacccactcggtctcaactccgacgcagataaaattccctttcaccctacttacct ataaagatctcctaggctttgcaattctaattatttgcctcaccgccettgctttattctcccgaatctcct cggagaccetgacaacttcaccccgecaacca cttgttactcctcccatattaaaccagaatgatacttc ctatttgcctatgccatcctacgctcaattccaaacaaactggacggagtcctggccetccttgcetccatcc tcgtcctcatagtagtccccattctccatacgtctaagcgacgaggactcaccetccgcccagccacccaact cctttttgaaccetaattgcagatgtcttcattctaacctgaattggtggcatacctgtagaacatccet tc atcatcatcggtcaaatcgcatccatcttatacttctccctcttcctcattttattcccacta

\section{c)}

cccacccactcctaaaaatcgctaacgacgcactggtagatctccccgccccatccaacatctcagcctgatg aaactttggatccetgctcggtctctgcttagccgcccaaatcctcacaggactcttcctagccatgcactac acagctgacatctccatagcettctcatcogtcgcgcacatttgccgagatgttaactacggctgactcatcc gaaacctccatgccaacggcgcetccttcttcttcatctgcctctacctccacatcggccgaggcctttacta cggctcctatctttacatagaaacatgaaacatcggggtcattcttttccttttagtaatgataaccgccttc gttggctatgtccttccatgaggtcaaatatctttctgaggtgccaccgtcattacaaaccttctgtctgctg taccgtatgtgggtaacacactagtccaatgaatttgaggaggattctccgtagacaacgccaccctcacccg cttcttcgcettccacttcctcctcccatttatcgtcacagctgctaccettctccacctacttttcctgcac gaaacaggatcaaacaacccactcggtctcaactccgacgcagataaaattccetttcacccctactttacct ataaagatctcctaggctttgcaattctaattatttgcctcaccgcccttgctttattctccccgaatctcct cggagaccetgacaacttcacccccgccaacccacttgttactcctccccatattaaaccagaatgatacttc ctatttgcctatgccatcctacgctcaattccaaacaaactggacggagtcctggcectccttgcctccatcc tcgtcctcatagtagtccccattctccatacgtctaagcgacgaggactcaccetccgcccagccacccaact ccttttttgaaccctaattgcagatgtcttcattctaacctgaattggtggcatacctgtagaacatcccttc atcatcatcggtcaaatcgcatccatcttatacttctccctcttcctcattttattcccacta b)

cccaccactcctaaaaatcgctaacgacgcactggtagatctccccgccccatccaacatctcagcetgatg aaactttggatccetgetcggtctctgcttagccgcccaatcctcacaggactcttcctagccatgcactac acagctgacatctccatagcettctcatccgtcgcgca catttgccgagatgttaactacggetgactcatcc gaaacctccatgccaacggegcctccttcttcttcatctgectctacctccacatcggccgaggectttacta cggctcctatctttacatagaaacatgaaacatcggggtcattctttccttttagtaatgataaccgecttc gttggctatgtccttccatgaggtcaaatatctttctgaggtgccaccgtcattacaaaccttctgtctgctg taccgtatgtgggtaacacactagtccaatgaatttgaggaggattctccgtagacaacgccaccctcacccg cttcttcgccttccacttcctcctccatttatcgtcacagctgctaccettctccacctacttttcctgcac gaaacaggatcaaacaaccactcggtctcaactccgacgcagataaaattccetttcacccetactttacct ataaagatctcctaggetttgcaattctaattatttgcc tcaccgccettgctttattctcccgaatctcct cggagaccctgacaacttcaccccgccaaccacttgttactcctcccatattaaaccagaatgatacttc ctatttgcctatgccatcctacgetcaattccaaacaaactggacggagtcctggecctccttgcctccatcc tcgtcctcatagtagtcccattctccatacgtctaagcgacgaggactcaccetccgcccagccaccaact ccttttttgaacctaattgcagatgtcttcattctaacctgaattggtggcatacctgtagaacatccettc atcatcatcggtcaatcgcatccatcttatacttctccetctcctcatttattcc cacta

\section{d)}

cccacccactcctaaaaatcgctaacgacgcactggtagatctcccegccccatccaacatctcagcetgatg aaactttggatccetgctcggtctctgcttagccgcccaaatcctcacaggactcttcctagccatgcactac acagctgacatctccatagcettctcatccgtcgcgcacatttgccgagatgttaactacggctgactcatcc gaaacctccatgccaacggcgectcettcttcttcatctgcctctacctccacatcggccgaggcetttacta cggctcctatctttacatagaaacatgaaacatcggggtcattctttccttttagtaatgataaccgccttc gttggctatgtccttccatgaggtcaaatatctttctgaggtgccaccgtcattacaaaccttctgtctgctg taccgtatgtgggtaacacactagtccaatgaatttgaggaggattctccgtagacaacgccaccctcacccg cttcttcgccttccacttcctcctcccatttatcgtcacagctg ctaccettctccacctacttttcctgcac gaaacaggatcaaacaacccactcggtctcaactccgacgcagataaaattccetttcaccctactttacct ataaagatctcctaggctttgcaattctaattatttgcctcaccgccettgctttattctccccgaatctcct cggagaccctgacaacttcaccccgecaacccacttgttactcctcccatattaaaccagaatgatacttc ctatttgcctatgccatcctacgctcaattccaaacaaactggacggagtcctggccetcettgcetccatcc tcgtcctcatagtagtccccattctccatacgtctaagcgacgaggactcaccetccgcccagccacccaact cctttttgaaccetaattgcagatgtcttcattctaacctgaattggtggcatacctgtagaacatccettc atcatcatcggtcaaatcgcatccatcttatacttctccetcttc ctcattttattcccacta

Figure 3. Cytochrome b sequence of Plagioscion sp. with respect to the additional MT analysis. White and gray backgrounds show the fragments yielded by the enzymes. (a), (b), (c) and (d) are the different RFLP profiles detected with Mbol, BmaHI, Alul and EcoRl enzymes, respectively. The underlined tetra/hexanucleotide segments denote the restriction sites of the enzymes.

Francesca et al. 2004, Bremer et al. 2005, Ferreira et al. 2005). Thus, the well-characterized cytochrome $b$ gene is particularly useful in the analysis of the relationship between recently diverged taxa (STEPIEN \& KOCHER 1997) and is a powerful mtDNA marker for species levels (MEYER 1994) since two specimens with different molecular profiles may be considered as different species (see PARSON et al. 2000 for details). Therefore, results herein that the two samples represent one species is supported by those studies, given the same molecular profile of cytochrome $b$ in both samples (Figs 2b, c, d, e). Furthermore, RFLPs detected Plagioscion squamosissimus as an introduction into the Paraná river, downstream to Itaipu, within the distribution of the endemic congener, Plagioscion ternetzi. Cryptic invasive fish have been discovered also in others environments by the use of molecular techniques (ColLins et al. 2002, HickEY et al. 2004).

Plagioscion squamosissimus is a top predator, with mostly fish comprising its diet (Braga 1998, Loubens 2003, Bennemann et al. 2006), and so its introduced occurrence may be an important threat to the native community, including the endemic congener Plagioscion ternetzi. Indeed, local fishermen have already noticed a decline in the abundance of $P$. ternetzi in their fish catch. The decline and ultimate extinction of native spe cies as a consequence of biological invasions have been documented for neotropical ichthyofauna (Mooney \& CLELANd 2001, Latini \& Petrere JR 2004).

The additional RFLP analysis described herein was to test the conclusions of the MT analysis with a cytochromeb sequence from a Plagioscion species (SLoss et al. 2004). Specific molecular profiles were identified for Plagioscion sp., in comparison with those from P. squamosissimus. Thus, while a single band of $900 \mathrm{bp}$ identified P. squamosissimus, five bands (38bp, 43bp, 71bp, 423bp, $510 \mathrm{bp}$ ) identified Plagioscion sp. (Figs $2 \mathrm{~d}$ and $3 \mathrm{a}$, respectively) by using $\mathrm{Mbol}$ enzyme. Using BamHI enzyme, a single band of 725bp was found in P. squamosissimus, while 2 bands (81bp and 1004bp) were found in Plagioscion sp. (Figs 2e and 3b). Using Alul, the best resolution enzyme, three bands were found for both P. squamosissimus and Plagioscion sp., but of different molecular weights (400, 275 and 225bp; Fig. 2c and 150, 402 and 533bp; Fig. 3c, respectively). EcoRI enzyme did not differentiate the samples due to absence of its restriction site in both species (Figs $2 \mathrm{~b}$ and $3 \mathrm{~d}$ ). Therefore, in comparing the geographical distributions among all Plagioscion species with that of Plagioscion

Revista Brasileira de Zoologia 23 (4): 1235-1242, dezembro 2006 
Table II. Survey of the size of cytochrome b gene for several fish species. The nomenclature used for taxonomic groups was based on Froese \& PAULI (2006).

\begin{tabular}{|c|c|c|c|c|}
\hline Species & Taxonomic group & $\begin{array}{c}\text { Gene } \\
\text { size }(b p)\end{array}$ & $\begin{array}{l}\text { Genebank } \\
\text { accession }\end{array}$ & Reference \\
\hline Myxine glutinosa (Linnaeus, 1758) & Agnatha/Myxiniformes & 1158 & Y15185 & RASMUSSEN et al. (1998) \\
\hline Chimaera monstrosa (Linnaeus, 1758) & Gnathostomata/Chimaeriformes & 1144 & AJ310140 & ARNASON et al. (2001) \\
\hline Carcharinus plumbeus (Nardo, 1827) & Gnathostomata/Elasmobranchii & 1146 & L08032 & MARTIN \& PALUMBI (1993) \\
\hline Latimeria chalumnae (Smith, 1939) & Acanthodii/Sarcopterygii & 1143 & NC001804 & ZARDOYA \& MEYER (1997) \\
\hline Lepidosiren paradoxa (Fitzinger, 1837) & Acanthodii/Sarcopterygii/Dipnoi & 1140 & AF302934 & BRINKMANN et al. (2004) \\
\hline Acipenser baerii (Brandt, 1869) & Actinopterygii/Chondrostei & 859 & AF238656 & BiRsten et al. (2000) \\
\hline Amia calva (Linnaeus, 1766) & Neopterygii/Amiiformes & 1140 & AB018999 & KumAZAWA et al. (1999) \\
\hline Lepisosteus spatula (Lacepède, 1803) & Neopterygii/Semionotiformes & 1141 & AP004355 & INOUE et al. (2003) \\
\hline Arapaima gigas (Schinz, 1822) & Teleostei/Osteoglossomorpha & 1141 & AB035241 & KumAZAwa et al. (1999) \\
\hline Elops hawaiensis (Regan, 1909) & Teleostei/Elopomorpha & 1152 & AB051070 & INOUE et al. (2004) \\
\hline Anguilla anguilla (Linnaeus, 1758) & Elopomorpha/Anguilliformes & 1140 & AP007233 & MINEGISHI et al. (2005) \\
\hline Sardinella aurita (Valenciennes 1847) & Teleostei/Clupeomorpha & 1141 & AF472584 & JEROME et al. (2003) \\
\hline Sardinops sagax (Girard 1854) & Teleostei/Clupeomorpha & 1141 & AF472585 & JeROME et al. (2003) \\
\hline Chanos chanos (Forsskål 1775) & Euteleostei/Anotophysi/Chanoidei & 1140 & AY504825 & LAVOue $\&$ SUшIVAN (2004) \\
\hline Gonorynchus greyi (Richardson 1845) & Euteleostei/Anotophysii/Gonorhyncoidei & 1141 & AB054134 & SAITOH et al. (2003) \\
\hline $\begin{array}{l}\text { Phenacogrammus interruptus (Boulenger } \\
\text { 1899) }\end{array}$ & Euteleostei/Otophysii/Characiformes & 1141 & AB018998 & KumAZAWA et al. (1999) \\
\hline Chalceus macrolepidotus (Cuvier, 1817) & Otophysii/Characiformes & 1141 & AB054130 & SAIтOH et al. (2003) \\
\hline Carassius auratus (Linnaeus, 1758) & Otophysii/Cypriniformes & 1141 & NC006580 & Unpublished (GeneBank) \\
\hline Apteronotus albifrons (Linnaeus, 1766) & Otophysii/Gymnotyformes & 1141 & AB054132 & SAIтOH et al. (2003) \\
\hline Eigenmannia sp. (Valenciennes, 1842) & Otophysii/Gymnotyformes & 1137 & AB054131 & SAITOH et al. (2003) \\
\hline $\begin{array}{l}\text { Hexanematichthys (Arius) platypogon } \\
\text { (Günther, 1864) }\end{array}$ & Otophysii/Siluriformes & 920 & AJ580996 & Unpublished (GeneBank) \\
\hline Bagre marinus (Mitchill, 1815) & Otophysii/Siluriformes & 920 & AJ581355 & Unpublished (GeneBank) \\
\hline Corydoras rabauti (La Monte, 1941) & Otophysii/Siluriformes & 1138 & AB54128 & SAIтOH et al. (2003) \\
\hline Salmo salar (Linnaeus, 1758) & Protachantopterygii/Salmoniformes & 1141 & NC001960 & HuRst et al. (1999) \\
\hline Alepocephalus tenebrosus (Gilbert, 1892) & Protachantopterygii/Argentiniformes & 1141 & AP004100 & ISHIGURO et al. (2003) \\
\hline Esox americanus (Gmelin, 1789) & Protachantopterygii/Esociformes & 1154 & AY497436 & Grande et al. (2004) \\
\hline Ateleopus japonicus (Bleeker, 1854) & Sternopterygii/Ateleopodiformes & 1141 & AP002916 & Mira et al. (2001) \\
\hline $\begin{array}{l}\text { Chauliodus sloani (Bloch \& Schneider, } \\
\text { 1801) }\end{array}$ & Sternopterygii/Stomiiformes & 1137 & NC002915 & KawAGUCH et al. (2001) \\
\hline Aulopus japonicus (Günther, 1877) & Cyclosquamata/Aloupiformes & 1141 & NC002674 & KaWAGUCHI et al. (2001) \\
\hline Aphredoderus sayanus (Gilliams, 1824) & Parachantopterygii/Percosiformes & 1141 & AP004403 & MiYA et al. (2003) \\
\hline $\begin{array}{l}\text { Porichthys myriaster (Hubbs \& Schultz, } \\
\text { 1939) }\end{array}$ & Parachantopterygii/Batrachoidiformes & 1180 & AP006739 & MiYA et al. (2005) \\
\hline Mugil cephalus (Linnaeus, 1758) & Acanthopterygii/Mugiliformes & 1138 & NC003182 & MIYA et al. (2001) \\
\hline Melanotaenia lacustris (Munro, 1964) & Acanthopterygii/Atheriniformes & 1140 & AP004419 & Mira et al. (2003) \\
\hline Mastacembelus favus (Hora, 1924) & Acanthopterygii/Synbranchiformes & 1138 & AP002946 & Mira et al. (2001) \\
\hline Oreochromis mossambicus (Peters, 1852) & Acanthopterygii/Perciformes & 1135 & NC007231 & Unpublished (GeneBank) \\
\hline Plagioscion sp. (Heckel, 1840) & Acanthopterygii/Perciformes & 1085 & AY374296 & Stoss et al. (2004) \\
\hline
\end{tabular}


sp. (SLoss et al. 2004) we suggest that the present molecular characterization could be attributed to Plagioscion montei (SOARES \& CASATTI 2000) since P. montei is the single species sampled for some river in Peru (also see SLoss et al. 2004).

Finally, the present approach suggests that molecular techniques may offer a very precise method of identifying biodiversity as well as recognizing invasive species. Therefore, we recommend the use of this tool in any study in which species richness need be tested, to test whether local samples represent actually native species, as well as to request the human responsibilities over the environmental impacts made.

\section{ACKNOWLEDGEMENTS}

To Walter A.P. Boeger, for help in collections and PCR as well as suggestionsfor improvement of the manuscript. To James J. Roper and to two anonymous referees for valuable suggestions in the manuscript. To Viviane M. Sass for her technical assistance and to Lilian Casatti (photos of P. squamosissimus and P. ternetzi). Grants supporting this study were provided by Programa Prodoc Capes/Ministry of Education/Brazilian Federal Government (Process number 00197/03-3).

\section{REFERENCES}

Aguilera, O. \& D.R. Aguilera. 2000. A new species of croaker Plagioscion (Perciformes; Sciaenidae) from Orinico river basin. Memória, Caracas, 153: 61-67.

Arnason,U.; A. Gullberg \& A. Janke. 2001. Molecular phylogenetics of gnathostomous (jawed) fishes: Old bones,new cartilage. Zoologica Scripta, Oxford, 30: 249-255.

Benedito-Cecilio, E. \& A.A. Agostinho. 2000. Distribution, abundance and use of different environments by dominant ichthyofauna in the influence area of the Itaipu reservoir. Acta Scientiarum, Maringá, 22 (2): 429-437.

Bennemann, S.T.; L.G. Capra; W. Galves \& O.A. Shibatta. 2006. Dinâmica trófica de Plagioscion squamosissimus (Perciformes, Sciaenidae) em trechos de influência da represa Capivara (rios Paranapanema e Tibagi). Iheringia, Série Zoologia, Porto Alegre, 96(1):115-119.

Birstein, V.J.; P. Doukakis \& R. DeSalle. 2000. Polyphyly of mtDNA lineages in the Russian sturgeon, Acipenser gueldenstaedtii: forensic and evolutionary implications. Conservation Genetics, Berlin, 1: 81-88,

Blaxter, M. \& R. Floyd. 2003. Molecular taxonomics for biodiversity surveys: al ready and reality. Trends in Ecology and Evolution, Oxford, 18 (6): 268-269.

Bradley, R.D. \& R.J. Baker. 2001. A test of the genetic species concept: cytochrome-b sequences and mammals. Journal of Mammalogy, Lawrence, 82 (4): 960-973.

Braga, F.M.S. 1998. Alimentação de Plagioscion squamosissimus (Osteichthyes, Sciaenidae) no reservatório de Barra Bonita, estado de São Paulo. Iheringhia, Série Zoologia, Porto Alegre, 84: 11-19.
Bremer, J.R.A.; M.G. Frisk; T.J. Miller; J. Turner; J. Viñas \& K. KWIL. 2005. Genetic identification of cryptic juveniles of little skate and winter skate. Journal of Fish Biology, Oxford, 66: 1177-1182.

Brinkmann, H.; A. Denk, J. Zitzler; J.J. Joss \& A. Meyer. 2004. Complete mitochondrial genome sequences of the South american and the Australian lungfish: testing of the phylogenetic performance of mitochondrial data sets for phylogenetic problems in tetrapod relationships. Journal Molecular Evolution, New York, 59 (6): 834-848.

Carnelos, R.C. \& E. Benedito-Cecilio. 2002. Reproductivestrategies of Plagioscion squamosissimus Heckel, 1840 (Osteichthyes Sciaenidae) in the Itaipu Reservoir. Brazilian Archives of Biology and Technology, Curitiba, 45 (3): 317-324.

ColauttI, R.I. \& H.J. MaclsaAc. 2004. A neutral terminology to define 'invasive' species. Diversity and Distributions, Oxford, 10: 135-141.

Collins, T.M.; J.C. Trexler; L. Nico \& T.A. Rawlings. 2002. Genetic diversity in a morphologically conservative invasive taxon: multiple introductions of swamp eels to the Southeastern United States. Conservation Biology, Arlington, 16 (4): 1024-1035.

Ferreira, J.M.; F.M. Martins; A. Ditchfield \& J.S. Morgante. 2005. The use of PCR-RFLP as an identification tool for two closely related species of bats of genus Platyrrhinus. Genetics and Molecular Biology, Riberão Preto, 28 (1): 120-122.

Francesca, V.; L. Lívia; M. Nadia; R. Bernardino; R. Ettore \& P. FAusto. 2004. A simple and rapid PCR-RFLP method to distinguishing $M$ artes martes and Martes foina. Conservation Genetics, Berlin, 5: 869-871.

Froese, R. \& D. Pauly. 2006. FishBase. Available in the World Wide Web at http://www.fishbase.org [accessed in 01.V. 2006].

Grande,T.; H. Laten \& J.A. Lopez. 2004. Phylogenetic relationships of extant esocid species (Teleostei: Salmoniformes) based on morphological and molecular characters. Copeia, Lawrence, 4: 743-757.

GRECHKo, V.V. 2002. Molecular DNA markers in phylogeny and systematics. Russian Journal of Genetics, Moscou, 38 (8): 851-868.

Hickey, A.J.R.; S.D. Lavery; S.R. Eyton \& K.D. Clements. 2004. Verifying invasive marine fish species using molecular techniques: a model example using triplefin fishes (Family Tripterygiidae). New Zealand Journal of Marine and Freshwater Research, Wellington, 38: 439-446

HuRst, C.D.; S.E. BartLetT; W.S. Davidson \& I.J. Bruce. 1999. The complete mitochondrial DNA sequence of the Atlantic salmon, Salmo salar. Gene, New York, 239: 237-242.

Inoue, J.G.; M. Miya; K. Tsukamoto \& M. Nishida. 2003. Basal actinopterygian relationships: a mitogenomic perspective on the phylogeny of the ancient fish. Molecular Phylogenetics and Evolution, Cambridge, 26: 110-120.

Inoue, J.G.; M. Miya; K. Tsukamoto \& M. Nishida. 2004. Mitoge-

Revista Brasileira de Zoologia 23 (4): 1235-1242, dezembro 2006 
nomic evidence for the monophyly of elopomorph fishes (Teleostei) and the evolutionary origin of the leptocephalus larva. Molecular Phylogenetics and Evolution, Cambridge, 32 (1): 274-286.

ISHIGURO,N.B.; M. MIYA \& M. NISHIDA. 2003. Basal euteleostean relationships: a mitogenomic perspective on the phylogenetic reality of the 'Protacanthopterygii. Molecular Phylogenetics and Evolution, Cambridge, 27: 476-488.

Jérôme, M.; C. Lemaire; J.M. Bautista; J. Fleurence \& M. Etienne, 2003. Molecular phylogeny and species identification of sardines. Journal of Agriculture and Food Chemistry, Columbus, 51 (1): 43-50.

KaWaguchi, A., M. Miya \& M. Nishida, 2001. Completemitochondrial DNA sequence of Aulopus japonicus (Teleostei: Aulopiformes), a basal Eurypterygii: Ionger DNA sequences and higher-level relationships. Ichthyological Research, Tokyo, 48, 213-223.

KumaZaWa, Y.; M. YAmaguchi \& M. NishidA, 1999. Mitochondrial molecular clocks and the origin of eutel eostean biodiversity: Familial radiation of perciforms may have predated the Cretaceous/Tertiary boundary, p: 35-52. In: M. KaTO (Ed). The biology of biodiversity. Tokyo, Springer-Verlag, 324p.

Latini, A.O. \& M. Petrere JR. 2004. Reduction of a native fish fauna by alien species: an examplefrom Brazilian freshwater tropical lakes. Fisheries Management and Ecology, Hull, 11: 71-79.

Lavoue, S. \& J.P. Sullivan, 2004. Simultaneous analysis of five molecular markers provides a well-supported phylogenetic hypothesis for the living bony-tongue fishes (Osteoglossomorpha: Teleostei). Molecular Phylogenetics and Evolution, Cambridge, 33 (1): 171-185.

Loubens, G. 2003. Biologie de Plagioscion squamosissimus (Teleostei: Sciaenidae) dans le bassin du Mamoré (Amazonie bolivienne). Ichthyological Exploration of Freshwaters, München, 14 (4): 335-352.

Martin, A.P. \& S.R. PAlumbi. 1993. Protein evolution in different cellular environments: cytochrome $b$ in sharks and mammals. Molecular Biology and Evolution, Oxford, 10: 873-891.

MCNeELy, J.A. 1996. Human dimensions of invasivealien species: how global perspectives are relevant to China, p. 169-181. In: P.J. Schel; S. Wang \& Y. XIE (Eds). Conserving China's biodiversity (II). Beijing, China Environmental Science Press, 257p.

MeYER, A. 1994. Shortcomings of the cytochrome $b$ gene as a molecular marker. Trends in Ecology and Evollution, Oxford, 9: 278-280.

Miller, S.A.; D.D. Dykes \& H.F. Polesky. 1988. A simple salting out procedure for extracting DNA from human nucleated cells. Nucleic Acids Research, Oxford, 16 (3): 1215.

Minegishi, Y.; J. Aoyama; J.G. Inoue; M. MiYa; M. Nishida \& K. TsuкAмото. 2005. Molecular phylogeny and evolution of the freshwater eels genus Anguilla based on the whole mitochondrial genome sequences. Molecular Phylogenetics and
Evolution, Cambridge, 34 (1): 134-146.

MiYa, M.; A. KaWAgUCHI \& M. Nishida. 2001. Mitogenomic exploration of higher teleostean phylogenies: a case study for moderate-scale evolutionary genomics with 38 newly determined complete mitochondrial DNA sequences. Molecular Biology and Evolution, Oxford, 18 (11): 1993-2009.

Miya, M.; H. Takeshima; H. Endo; N.B. Ishiguro; J.G. Inoue; T. Mukal; T.P. Satoh; M. Yamaguchl; A. Kawaguchl; K. Mabuchl; S.M. SHIRAI \& M. NISHIDA. 2003. Major Patterns of higher teleostean phylogenies: A new perspective based on 100 complete mitochondrial DNA sequences. Molecular Phylogenetics and Evolution, Cambridge, 26: 121-138.

MiYA, M.; T.P. SATOH \& M. NishidA. 2005. The phylogenetic position of toadfishes (order Batrachoidiformes) in the higher ray-finned fish as inferred from partitioned Bayesian analysis of 102 whole mitochondrial genome sequences. Biological Journal of the Linnean Society, London, 85: 289-306.

Moysés, C.B. \& L.F. Almeida-Toledo. 2002. Restriction Fragment Lenght Polymorphisms of mitochondrial DNA among five freshwater species of the genus Astyanax (Pisces, Characidae). Genetics and Molecular Biology, Ribeirão Preto, 25 (4): 401-407.

Mooney, H.A. \& E.E. Cleland. 2001. The evolutionary impact of invasive species. Proceedings of the National Academy of Sciences USA, Washington, 98 (10): 5446-5451.

PALO, J.U. \& J. MeRILÄ. 2003. A simple RFLP method for identification of two ranid frogs. Conservation Genetics, Berlin, 4: 801-803.

Parson, W.; Pegoraro, K.; Niederstätter, H.; M. Föger. \& M. SteinLECHNER 2000. Species identification by means of the cytochrome b gene. International Journal of Legal Medecine, Berlin, 114: 23-28.

Rasmussen, A.S.; A. Janke \& U. Arnason. 1998. The mitochondrial DNA molecule of the hagfish (Myxine glutinosa) and vertebrate phylogeny. Journal of Molecular Evolution, New York, 46 (4): 382-388.

Riddle, A.E.; K.L Pilgrim; L.S. Mills; K.S. McKelveY; \& L.F. Ruggiero. 2003. Identification of mustelids using mitochondrial DNA and non-invasive sampling. Conservation Genetics, Berlin, 4: 241-243.

SaItoh, K.; M. Miya; J.G. InOue; N.B. Ishiguro \& M. Nishida, 2003. Mitochondrial genomics of ostariophysan fishes: perspectives on phylogeny and biogeography. Journal of Molecular Evolution, New York, 56 (4): 464-472.

Santos, S.; H. Schneider \& I. Sampaio. 2003. Genetic differentiation of Macrodon ancylodon (Sciaenidae, Perciformes) populations in Atlatic coastal waters of South America as revealed by mtDNA analysis. Genetics and Molecular Biology, Ribeirão Preto, 26 (2): 151-161.

Sloss, B.L.; N. Billington \& B.M. Burr. 2004. A molecular phylogeny of the Percidae (Teleostei, Perciformes) based on mitochondrial DNA sequence Molecular Phylogeneticsand 
Evolution, Cambridge, 32 (2): 545-562

SoARes, L.H. \& L. CasatTı. 2000. Descrição de duas novas espécies de Sciaenidae (Perciformes) de água doce da bacia Amazônica. Acta Amazônica, Manaus, 30 (3): 499-514.

Stepien, K. \& T.D. Kocher. 1997. Molecules and morphology in studies of fish evolution, p. 1-11. In: T.D. Kocher \& K. STEPIEN (Eds). Molecular systematics of fishes. San Diego, Academic Press, 314p.

Torloni, C.E.C.; J.J. SAntos; A.A.C. Junior \& A.R.A. CorrêA. 1993. A pescada do Piauí Plagioscion squamosissimus (HeCKel
1840) (Osteichthyes, Perciformes) nos reservatórios da Companhia Energética de São Paulo - CESP. São Paulo, CESP, Série Pesquisa e Desevolvimento, 23p.

WhelAN, S.; P. LIÒ \& N. Goldman. 2001. Molecular phylogenetics: state-of-theart methods for looking into the past. Trends in Genetics, Oxford, 17 (5): 262-272.

ZARDOYA, R. \& A. MeYer. 1997. The complete DNA sequence of the mitochondrial genome of a 'livingfossil,' the coelacanth (Latimeria chalumnae). Genetics, Pittsburgh, 146 (3): 9951010.

Received in 13.III.2006; accepted in 21.XI.2006. 